\title{
The Impact of the Amount of Fees for the Collection and Management of Municipal Waste on the Percentage of Selectively Collected Waste
}

\author{
Agnieszka Petryk ${ }^{1}$, Mateusz Malinowski², Magdalena Dziewulska², Sylwia Guzdek ${ }^{3}$ \\ 1 Cracow University of Economics, Department of Regional Economy. ul. Rakowicka 27, 31-510 Kraków, Poland \\ 2 Department of Bioprocesses Engineering, Energetics and Automatization. Faculty of Production and Power \\ Engineering, University of Agriculture in Cracow, ul. Balicka 116b, 30-149 Kraków, Poland \\ ${ }^{3}$ Cracow University of Economics, Department of Microeconomics. ul. Rakowicka 27, 31-510 Kraków, Poland \\ * Corresponding author's e-mail: agnieszka.petryk@uek.krakow.pl
}

\begin{abstract}
The changes in the waste management system that have been introduced in Europe and in the world were aimed at counteracting the emergence of illegal dumping sites and increasing the levels of waste recovery and recycling, so that waste management remains in line with the principles of sustainable development and circular economy. The change introduced in 2013 in the municipal waste management system in Poland concerned the assumption of full responsibility by municipalities for the municipal waste collected from owners of residential properties, as well as the establishment and organization of a charging system for residents for the collection and management of the waste. The purpose of the study was to conduct a comparative analysis of fees paid by residents of 93 selected communes of the Lubelskie Province. The study examined the impact of the amount of fees for the waste collection and management on the share of households declaring selective municipal waste collection, the share of selectively collected waste, and the mass accumulation rate of municipal waste. As a result of the analysis conducted using the data from the years 2013-2016, it was revealed that the amount of fees for the collection and management of waste in households that sorted waste contributed significantly to the increase in the percentage of selectively collected waste. Similarly, the smaller the value of the ratio of rates for sorted and mixed waste, the greater the segregation efficiency. This indicates that in the case of the analyzed region, the lower fee charged for sorting waste was an incentive for residents to sort waste.
\end{abstract}

Keywords: municipal solid waste, waste management, waste collection, waste management fees

\section{INTRODUCTION}

The system of municipal solid waste (MSW) management in Poland, operating since 2013, assumes that the authorities of the local government units are responsible for collection and proper waste management [Journal of Laws 2011, item 897 , as amended and further referred to as the Act on maintaining cleanliness and order in municipalities/communes (AMCOM)]. In this system, the commune influences each of its elements and thus can shape the way municipal waste is managed in its area [Kołaczek 2012]. Currently, all residents of Poland are obliged to render waste.
By means of a resolution, the commune council determines the rates of the fee for municipal waste management as well as the date, frequency and mode of its payment. The fee includes the costs of collection, transport, recovery and disposal of waste, creation and maintenance of selective waste collection points, as well as the costs of administrative service of the system. The municipality/commune is obliged to award either a public contract for the collection of municipal waste from property owners, or a public contract for the collection and management of the waste through a tender or an "in house" contract [Journal Laws of 2016, item 250]. As mentioned by Malinowski 
[2014], the lowest price offered for the service is usually the main criterion for selecting a task contractor in the tender procedures conducted by communes. This approach caused that the environmental aspect of the Act took secondary priority to economic aspects. Steinhoff-Wrześniewska [2015] notes that at the time of system changes, communes did not hold credible data so as to establish a reliable waste management plan. If the planned financial means obtained for waste management are insufficient, the commune is obliged to add money from its budget and increase fees. The surplus funds gained from waste management can be allocated by the commune solely to the functioning of the system, e.g. creation of selective collection points, educational campaigns, etc. [Journal of Laws of 2016, item 250].

Currently, the fees depend on the characteristics of households where waste is generated. However, Dijkgraaf and Gradus [2009], Sakai et al. [2008] and van Beukering et al. [2009] showed the benefit of using fees based on the weight of waste. These benefits have a financial, social and educational dimension. More and more municipalities in Europe are implementing a "unit based pricing" system. Unfortunately, there are still cases of illegal dumping sites in such municipalities/ communes. In Poland, the fees for waste were made independent of the mass of the waste generated. Thus, the principle of charging equal and relatively low fees was adopted. In this way, the government wanted to motivate property owners to dispose of all generated waste for management, and not to illegal landfills.

As indicated above, the obligation to determine the amount of fees alone for the collection and transport of municipal waste lies with the municipality/commune, which is a difficult task due to the fact that the local community largely does not accept the need to incur the fees for the recovery of municipal waste, and at the same time, this rate should balance the revenues from the fees paid by individual and collective producers with the costs of the recovery system operation [Golen 2014]. The general principles of calculating the fee are set out in the Act on maintaining cleanliness and order in municipalities Civil Code in Article 6i. They vary depending on the type of real estates:

- inhabited real estates - for each month in which a resident lives in a given estate,

- uninhabited real estates - for each month in which municipal waste was generated in the estate.
The provisions of AMCOM give the commune the opportunity to choose one of the methods of calculating the fees. The fees are also differentiated depending on whether the waste is collected selectively or not. There are the following options for the inhabited estate:

1. the product of the rate set by the commune council and the number of persons living in the estate,

2. the product of the amount of water consumed by a given estate and the rate of the fee determined by the commune council,

3. the product of the floor area of the housing unit and the rate of the fee set by the commune council,

4. the rate from the household set by the commune council.

The methods for determining the amount of fees (flat rate, or quantity-based charge) in Poland are described in detail in the papers of: Terek and Piotrowska [2013], Kiepas-Kokot et al. [2015] and Malinowski et al. [2019].

The flat rate has become popular in many developed and developing countries because of easy handling and constant revenue generation [Töpfer, 2005]. However, some developing countries are facing a problem of fees which do not cover the cost of waste management sufficiently. The quantity-based charge method is also known as the "unit pricing" or "pay as you throw" [Chang et al., 2008]. This method is popular in many countries i.e. in Denmark, Finland, Sweden, the Netherlands [Dijkgraaf, Gradus, 2009; van Beukering et al., 2009], and Belgium [Gellynck and Verhelst, 2007] due to its ability to give a clear price signal; hence, encouraging households to reduce their waste. Moreover, Dahlén and Lagerkvist [2010] claim that the changes in the fee rate or in the method of its setting, often resulting in an increase in the fee rate, lead to a reduction of the municipal waste generated and to an increase in the share of waste directed to the composting or recycling processes. Boas Berg et al. [2017, 2018] and Lichovníková [2015] presented the issue using the examples of individual communes in the Czech Republic.

In Poland, there are no analyses that could indicate the impact of fee rates on the amount of waste collected in a selective manner. A few authors conducted the analyses of the amount of fees. Malinski et al. [2019] report that in the Silesian region, the average fee charged to the 
residents of the analyzed communes in the years 2013-2016 for the collection and management of mixed waste in the analyzed area amounted to PLN 14.1, whereas when the residents decided to collect waste also in a selective manner, the rate was halved and amounted to PLN 7.3. During the period in question, the waste collection fee in most communes increased by $34 \%$. KiepasKokot et al. [2015] average fee for waste management regions of the West Pomerania Province calculated for mixed waste management was between 13.24 and $18.52 \mathrm{PLN} /$ person/month, for waste collected selectively between 8.67 and 12.35 PLN/person/month. Terek and Piotrowska [2013] calculated that the fee for collecting municipal waste from the people who sorted waste was in the range of PLN 2.5-15 per person. The average fee was PLN 8.5 per person. However, when the waste was not collected selectively, the fee increased by an average of $40 \%$ and was in the range of PLN 7-25 per person.

The article presents an analysis of the amount of fees for waste collection and management in selected communes of the Lubelskie Province, incurred by residents in the years 2013-2016. A comparative analysis of communes among themselves in terms of the changes in the fee rates was conducted, and the impacts of the amount of fees paid on the mass and accumulation of collected waste (mixed and sorted), as well as the share of waste collected in a selective manner (effectiveness of selective waste collection) were determined.

\section{MATERIAL AND METHODOLOGY OF RESEARCH}

The research area included: Lubelski and Puławy subregions, which are located in the Western part of the Lubelskie Province and border with the following provinces: Mazowieckie, Świętokrzyskie and Podkarpackie. The administrative division of the research area includes 10 land poviats, 1 town poviat, 93 communes, including 8 urban communes, 13 urban-rural communes and 72 rural communes (Figure 1). The analyzed area covers $9854.1 \mathrm{~km}^{2}$ and the population exceeds 1.2 million.

The economy of the region is based on agriculture. The province is the national leader in the harvest of fruit from shrubs and berry plantations (48\% of national harvest in 2013) [CSO], the production of edible legumes, cereals, sugar beet and potatoes is also significant. The spa treatment and production of mineral waters (Nałęczowianka and Cisowianka) developed owing to the natural mineral water resources.

In 2017 and 2018, 93 Municipal Offices from this region were requested to share the information necessary to prepare the characteristics of waste management fees. All surveyed communes responded. The data for the analysis were also obtained from online Public Information Bulletins of municipal/commune offices and by means of direct contact with the employees of departments dealing with municipal waste management in the analyzed municipalities/communes. The data obtained concerned the amounts of fees charged for waste collection and management for the years 2013-2016: the rate (per person, $\mathrm{m}^{2}$, water, etc. depending on the adopted criterion) depending on the collection of waste that is with segregation (selective collection) and without segregation (only mixed waste), the number of inhabitants of the commune in the years 2013-2016, the number of declarations submitted, broken down into households declaring waste segregation and its absence, weight of collected waste in the years 2013-2016 broken down into its type (or copies of annual reports submitted by municipalities to the province marshal). The attained data, submitted in the form of scans of reports submitted by the enterprises servicing municipalities/communes in the scope of municipal waste collection, were added and verified with the information made

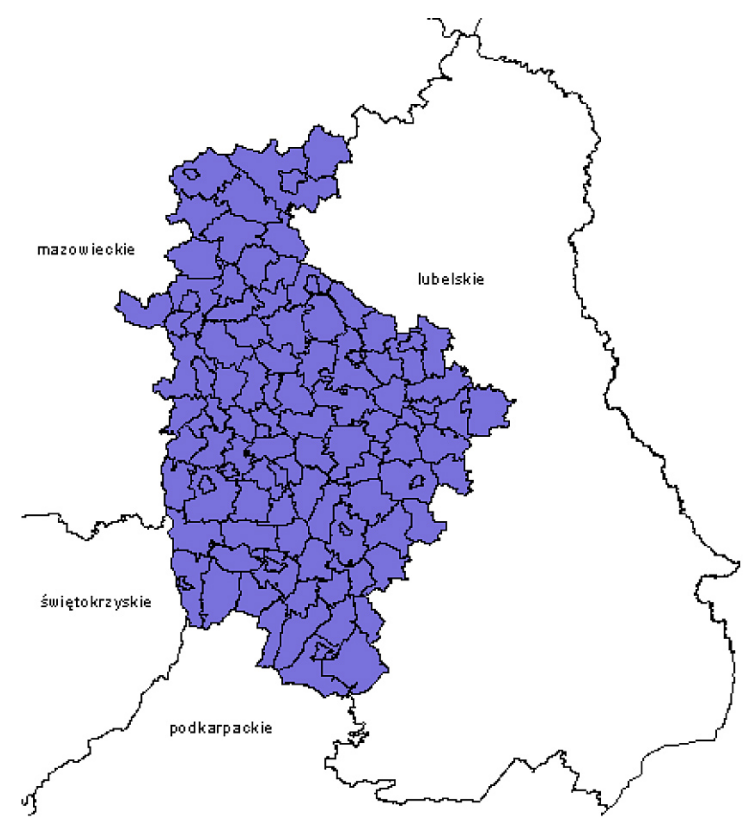

Figure 1. Research area 
available by the Marshal's Office of the Lublin Province. Using the data compiled in a spreadsheet for each of the municipalities, the following indicators were calculated based on the formulas presented by Malinowski et al. [2019]:

- calculation of the mean index of municipal solid waste accumulation:

$$
W_{m}=\frac{\left(\frac{M_{2013}}{L_{2013}}\right)+\left(\frac{M_{2014}}{L_{2014}}\right)+\left(\frac{M_{2015}}{L_{2015}}\right)+\left(\frac{M_{2016}}{L_{2016}}\right)}{4} \cdot 1000
$$

where: $W_{m}$ - index of municipal solid waste accumulation, [kg per person per year]; $M_{2013^{\prime}}, M_{2014^{\prime}} M_{2015^{\prime}}, M_{2016^{\prime}}$, total weight of municipal solid waste collected from residents of the municipality in 2013, 2014, 2015 and 2016, respectively [Mg]

$M_{2013^{\prime}}, M_{2014}, M_{2015}, M_{2016}$ - number of municipality residents respectively in the examined years

- calculation of the share of sorted municipal waste in the stream of all municipal waste collected from residents of the municipalities in 2013, 2014, 2015 and 2016 based on the formula:

$$
U_{s}=\frac{M_{s}}{M_{S}+M_{z}} \cdot 100[\%]
$$

where: $U_{s}$ - share of sorted municipal waste in the entire municipal waste stream in a specific year, [\%];

$M_{s}$ - weight of sorted municipal waste collected from residents of the municipality in a specific year, $[\mathrm{Mg}]$;

$M_{z}$ - weight of mixed municipal waste collected from residents of the municipality in a specific year, $[\mathrm{Mg}]$.

- specification of the effectiveness of waste segregation by calculating the mean share of sorted waste in the stream of all municipal waste during the research period, Us calculated as an arithmetic mean of shares for the four years.

- share of households declaring selective municipal waste collection

$$
\mathrm{W}_{\mathrm{D}}=\frac{\mathrm{D}_{\mathrm{s}}}{\mathrm{D}_{\mathrm{s}}+\mathrm{D}_{\mathrm{z}}} \cdot 100(\%)
$$

where: $W_{D}-$ share of households declaring selective municipal waste collection in the municipality/commune in [\%], $D_{S}$ - the number of households declaring selective municipal waste collection in a municipality/commune in the year [-]
$D_{z}$ - the number of households declaring a non-selective collection of municipal waste in the municipality/commune in the year [-],

- a change in the amount of the fee for collection and management of selectively collected municipal waste in the years $2013-2016$ :

$$
Z_{z, s}=\left(\left(\frac{O p_{z, S} 2016}{O p_{z, S} 2013}\right)-1\right) \cdot 100
$$

where: $Z_{Z, S}-$ the change in the rate for the collection and management of mixed municipal waste (z) and selectively collected waste (s), [\%];

$O p_{Z, S 2016}$ - the rate for the collection and management of mixed municipal waste (z) and selectively collected waste (s) in 2016, [PLN $\cdot$ (person $\cdot$ months $\left.)^{-1}\right]$;

$O p_{Z, S 2013}$ - the rate for the collection and management of mixed municipal waste (z) and selectively collected waste (s) in 2013, [PLN $\cdot$ (person $\cdot$ months $\left.)^{-1}\right]$,

- the ratio of the fees for the collection and management of sorted municipal waste to the fee for the collection and management of mixed municipal waste (the analysis of this indicator is extremely relevant from a cognitive point of view, as it directly indicates the involvement of the municipality/commune in the process of creating incentives for selective waste collection):

$$
\mathrm{W}_{\mathrm{o}}=\frac{\mathrm{S}_{\mathrm{s}}}{\mathrm{S}_{\mathrm{z}}} \cdot 100(\%)
$$

where: $W_{o}$ - the ratio of the average rate for the collection and management of sorted municipal waste to the average rate for the collection and management of mixed municipal waste in the municipality/ commune (\%),

$S_{S}$ - the average rate (fee) for collection and management of segregated municipal waste per inhabitant in the municipality/ commune in the years 2013-2016 (PLN), $S_{Z}$ - the average rate (fee) for the collection and management of mixed municipal waste per inhabitant in the municipality/commune (i) in the years 2013-2016 (PLN). 
For the mean values of analyzed fee rates and aforementioned indices (at the level of the whole area, as well as by municipalities, rural and urban-rural communes) standard deviation values were calculated and presented in the article. The statistical analysis (correlation coefficient) was performed using the Statistica 12.0 package.

\section{RESULTS AND DISCUSSION}

\section{Indicator of mass accumulation of municipal waste}

The average rate of mass accumulation of mixed municipal waste for the studied area was $128.8 \pm 58.8$ kg.person- 1 and was lower than half of the national average of $268 \mathrm{~kg}$.person-1 in 2014 [KPGO (National Waste Management Plan) 2022]. The minimum, maximum and mean values of the mass index of mass accumulation of waste broken down into urban, urban-rural and rural communes as well as the mean for the entire region, are presented in Table 1. Among the urban communes, the highest value of the indicator was recorded in the Lublin Municipality (317.7 kg.person-1), which is the seat of the province authorities.

\section{Share of households declaring selective waste collection and share of municipal waste collected selectively}

Since 2013, an increase in the weight of selectively collected waste has been observed in Poland. In the years 2012-2016 there was a nearly 3 -fold increase in the mass of the waste. In 2016, the share of selectively collected waste in the total weight of municipal waste collected in Poland amounted to 25.2\% (CSO 2017). In the analyzed area, the average share of waste

Table 1. Values of the index of mass accumulation of municipal waste

\begin{tabular}{|c|c|c|c|c|}
\hline \multirow{2}{*}{ No. } & Commune & $\begin{array}{c}\text { Minimum } \\
\text { value } \mathrm{W}_{1}\end{array}$ & $\begin{array}{c}\text { Maximum } \\
\text { value } \mathrm{W}_{1}\end{array}$ & $\begin{array}{c}\text { Mean value } \\
\mathrm{W}_{1}\end{array}$ \\
\cline { 2 - 5 } & Unit & kg person $^{-1}$ & kg.person $^{-1}$ & kg.person $^{-1}$ \\
\hline 1. & Urban & 186.6 & 317.7 & $246.6 \pm 45.1$ \\
\hline 2. & Urban-rural & 78.8 & 277.5 & $174.7 \pm 53.6$ \\
\hline 3. & Rural & 53.2 & 230.7 & $107.1 \pm 36.7$ \\
\hline & $\begin{array}{c}\text { IN TOTAL - } \\
\text { REGION }\end{array}$ & 53.2 & 317.7 & $128.7 \pm 58.8$ \\
\hline
\end{tabular}

collected selectively was $29.7 \pm 10.8 \%$ in the years 2013-2016, while the largest one was evident in the rural communes and amounted to 31.5 $\pm 9.9 \%$ (Table 2 ). These values indicate a high level of ecological awareness of the inhabitants of this region and are definitely higher than the national average and the results of the research by Malinowski et al. (2019) for the Częstochowa region of waste management, which amounted to $22.6 \%$ for the whole region and $21.8 \%$ for rural areas, respectively.

It is relevant from a cognitive point of view that the high proportion of waste collected selectively in rural areas did not result from a large percentage of residents' declarations submitted there regarding the choice of this type of waste collection (Table 3). The correlation coefficient equaled only to 0.08 . As stated by Malinowski et al. [2019], it is simply easier for the residents in rural areas to collect waste in a selective manner, which is confirmed by the data presented in Tables 2 and 3 (in 73 analyzed communes the percentage of households declaring selective waste collection exceeding 90\%). This is related to, for instance, the availability of containers and their location near households. Furthermore, the rural dwellers take greater care while sorting waste. As for blocks of flats in urban areas, the responsibility for the segregation of waste is assumed by all dwellers of the entire block, no matter if individuals sort waste or not. The problem is still the share of impurities in selectively collected waste [Malinowski et al. 2018].

\section{The analysis of the amount of fees for collection and management of municipal waste}

In most of the analyzed communes, the fee for the collection and management of municipal waste was calculated depending on the number

Table 2. Share of sorted municipal waste in the municipal waste stream (W2 index )

\begin{tabular}{|c|c|c|c|c|}
\hline \multirow{2}{*}{ No. } & Commune & $\begin{array}{c}\text { Minimum } \\
\text { value } \mathrm{W}_{2}\end{array}$ & $\begin{array}{c}\text { Maximum } \\
\text { value } \mathrm{W}_{2}\end{array}$ & $\begin{array}{c}\text { Mean } \\
\text { value } \mathrm{W}_{2}\end{array}$ \\
\cline { 2 - 5 } & Unit & $\%$ & $\%$ & $\%$ \\
\hline 1. & Urban & 11.8 & 62.7 & $24.1 \pm 16.5$ \\
\hline 2. & Urban-rural & 10.1 & 38.2 & $23.1 \pm 7.2$ \\
\hline 3. & Rural & 10.9 & 63.6 & $31.5 \pm 9.9$ \\
\hline & $\begin{array}{c}\text { IN TOTAL }- \\
\text { REGION }\end{array}$ & 10.1 & 63.6 & $29.7 \pm 10.8$ \\
\hline
\end{tabular}


of people living in a given estate. This quite common method has been used for a long time and its advantage is the low cost of its implementation [Grzymała et al. 2013]. The fees in municipalities/communes in which a different system had been adopted were converted into unit rates per inhabitant, so that the communes could be compared with each other. The fees to be paid monthly by the inhabitants of the analyzed region for waste collection and management ranged from PLN 3.4 to PLN 22 (Tables 4 and 5). The fees incurred by the residents who sorted waste were half as compared to the fees incurred by the residents who did not sort waste (the reduction in municipalities was $37 \%$ on average). The average fee for the analyzed municipalities/communes for collecting waste in a selective manner was $7.1 \pm 2.8$ PLN x (person $\mathrm{x}$ month)-1(Table 4). If only mixed waste was collected in the household, the average fee increased to $13.7 \pm 3.8$ (Table 5).

The fee rates calculated for the analyzed communes are almost identical to the rates for the Śląskie Province (Malinowski et al. 2019), which amounted to $14.1 \pm 1.9$ PLN for mixed waste (person $x$ month)- 1 and for sorted waste 7.3 \pm 1.1 PLN $\mathrm{x}$ (person $\mathrm{x}$ month)-1, which indicates a certain consistence of communes in determining these

Table 3. Share of households declaring selective municipal waste collection

\begin{tabular}{|c|c|c|c|c|}
\hline \multirow{2}{*}{ No. } & Commune & $\begin{array}{c}\text { Minimum } \\
\text { value } \mathrm{W}_{3}\end{array}$ & $\begin{array}{c}\text { Maximum } \\
\text { value } \mathrm{W}_{3}\end{array}$ & $\begin{array}{c}\text { Mean } \\
\text { value } \mathrm{W}_{3}\end{array}$ \\
\cline { 2 - 5 } 1. & Unit & $\%$ & $\%$ & $\%$ \\
\hline 2. & Urban & 72.8 & 95.6 & $89.8 \pm 6.6$ \\
\hline 3. & Rural & 42.9 & 99.9 & $94.5 \pm 4.8$ \\
\hline & $\begin{array}{c}\text { IN TOTAL- } \\
\text { REGION }\end{array}$ & 42.9 & 99.9 & $94.0 \pm 5.1$ \\
\hline
\end{tabular}

Table 4. Average fees for collection and management of segregated municipal waste per inhabitant and per month (SS)

\begin{tabular}{|c|c|c|c|c|}
\hline \multirow{2}{*}{ No. } & Commune & $\begin{array}{c}\text { Minimum } \\
\text { value Ss }\end{array}$ & $\begin{array}{c}\text { Maximum } \\
\text { value Ss }\end{array}$ & $\begin{array}{c}\text { Mean } \\
\text { value Ss }\end{array}$ \\
\cline { 2 - 5 } & Unit & $\begin{array}{c}\text { PLN } x \\
\text { (person } x \\
\text { month) }\end{array}$ & $\begin{array}{c}\text { PLN } x \\
\text { (person } x \\
\text { month) }^{-1}\end{array}$ & $\begin{array}{c}\text { PLN } x \\
\text { (person } x \\
\text { month }^{-1}\end{array}$ \\
\hline 1. & Urban & 5.5 & 16.3 & $9.5 \pm 3.2$ \\
\hline 2. & Urban-rural & 5.7 & 14.0 & $7.9 \pm 2.2$ \\
\hline 3. & Rural & 3.4 & 16.5 & $6.7 \pm 2.7$ \\
\hline & $\begin{array}{c}\text { IN TOTAL- } \\
\text { REGION }\end{array}$ & 3.4 & 16.5 & $7.1 \pm 2.8$ \\
\hline
\end{tabular}

rates. They also fall within the ranges given in the publication [Terek and Piotrowska, 2013].

The statistical analysis of the collected data showed that the amount of the fee for waste in households in which it was sorted in the analyzed area significantly affected the mass of the collected sorted waste $(r=-0.44)$. The smaller the amount of the fee, the greater the share of sorted waste and the greater its mass $(r=-0.49)$. The amount of the fee for mixed waste does not significantly correlate with any of the indicators analyzed. In the Silesian region analyzed in the same aspect [Malinowski et al. 2019], the correlation between the aforementioned indicators was not statistically significant. A considerably higher share of sorted waste may be noteworthy in the Lublin region than in the Silesian region (the average higher by 7 percentage points).

Table 6 summarizes the values of indicators informing about the ratio (quotient) of the rate for collection and management of sorted municipal waste to the amount of the rate for collection and management of mixed municipal waste. In addition, the table presents the changes in the fees in the analyzed period. In the analyzed period, the prices remained at a similar level. Malinowski et al. [2019] report that in the Silesian region in the same period, the fees increased by $34 \%$ compared to the base amount from 2013.

Theoretically, the lower the value of the rate relation, the greater the financial incentive for selective waste collection should be. This correlation is confirmed by the analysis of the correlation coefficient $(r=-0.46)$. This relationship is statistically significant. This correlation is mainly visible for urban areas $(r=-0.77)$, where the lower the ration of the fees (for sorted and mixed waste), the greater the proportion of waste collected selectively.

Table 5. Average fees for collection and management of mixed municipal waste per inhabitant and per month (Sz)

\begin{tabular}{|c|c|c|c|c|}
\hline \multirow{2}{*}{ No. } & Commune & $\begin{array}{c}\text { Minimum } \\
\text { value Sz }\end{array}$ & $\begin{array}{c}\text { Maximum } \\
\text { value Sz }\end{array}$ & $\begin{array}{c}\text { Mean } \\
\text { value Sz }\end{array}$ \\
\cline { 2 - 5 } & Unit & $\begin{array}{c}\text { PLN } x \\
\text { (person } x \\
\text { month })^{-1}\end{array}$ & $\begin{array}{c}\text { PLN } x \\
\text { (person } x \\
\text { month) }^{-1}\end{array}$ & $\begin{array}{c}\text { PLN } x \\
\text { (person } x \\
\text { month) }^{-1}\end{array}$ \\
\hline 1. & Urban & 11.5 & 21.3 & $15.0 \pm 3.4$ \\
\hline 2. & Urban-rural & 9.5 & 21.0 & $13.7 \pm 2.7$ \\
\hline 3. & Rural & 6.8 & 22.0 & $13.5 \pm 6.7$ \\
\hline & $\begin{array}{c}\text { IN TOTAL- } \\
\text { REGION }\end{array}$ & 6.8 & 22.0 & $13.7 \pm 3.8$ \\
\hline
\end{tabular}


Table 6. The relation between the rate for collection and management of sorted municipal waste and the rate for collection and management of mixed municipal waste and changes in these rates in 2013-2016

\begin{tabular}{|c|c|c|c|c|}
\hline \multirow[t]{2}{*}{ No. } & Commune & $\begin{array}{l}\text { Ratio of } \\
\text { the fee } \\
\text { for sorted } \\
\text { waste to } \\
\text { the fee } \\
\text { for mixed } \\
\text { waste }\end{array}$ & $\begin{array}{l}\text { Change in } \\
\text { the amount } \\
\text { of the fee } \\
\text { for collecting } \\
\text { mixed waste } \\
\text { in the years } \\
2013-2016\end{array}$ & $\begin{array}{c}\text { Change in } \\
\text { the fee for } \\
\text { collecting } \\
\text { sorted } \\
\text { waste in } \\
\text { the years } \\
2013- \\
2016\end{array}$ \\
\hline & Unit & $\%$ & $\%$ & $\%$ \\
\hline 1. & Urban & 63.0 & +21.2 & +13.6 \\
\hline 2. & Urban-rural & 57.7 & +4.9 & +6.4 \\
\hline \multirow[t]{2}{*}{3.} & Urban & 51.5 & +6.5 & +5.8 \\
\hline & $\begin{array}{l}\text { IN TOTAL- } \\
\text { REGION }\end{array}$ & 53.4 & +7.5 & +6.6 \\
\hline
\end{tabular}

\section{CONCLUSION}

In the years 2013-2016, the average amount of the fee for collection and management of sorted waste from the inhabitants of the analyzed region was PLN $7.1 \pm 2.8$ (person $x$ month)-1. On the other hand, in the same period, the average fee for collection and management of mixed waste from residents was PLN 13.7 \pm 3.8 (person x month)- 1 . The rates for collection increased significantly at that time (the increase concerned both the residents who sorted waste and those who did not). The average share of the sorted municipal waste stream in the total stream of collected waste in the period and region in question was $29.7 \%$, which proves the high ecological awareness of the inhabitants of the analyzed region. As a result of the aforementioned analyses, it was found that the fee charged to residents who sort waste stimulates their quantity. The smaller the fee and the smaller the value of the ratio of the rates for sorted and mixed waste, the greater the share of sorted waste.

\section{Ackonwledgment}

The publication was created as part of the statutory research No. 087/ WGAP-KGR/01/2019/S/9087

\section{REFERENCES}

1. Act of July 1, 2011 amending the Act on maintaining cleanliness and order in communes and some other Acts (Journal of Laws 2011, item 897).
2. Act of September 13, 1996 on maintaining cleanliness and order in communes (published text: Journal of Laws of 1996, item 662); codified text, Journal of Laws of 2016, item 250.

3. Boas Berg A., Radziemska, M., Adamcová D., Zloch, J., Vaverková, M.D. 2018. Assessment Strategies for Municipal Selective Waste Collection Regional Waste Management. Journal of Ecological Engineering, 19(1), 33-41.

4. Boas Berg A., Zloch, J., Radziemska, M., Adamcová D., Vaverková, M.D. 2017. Waste management law by example of a small European commune. Infrastructure and Ecology of Rural Areas, 4(1), 1329-1341.

5. Chang Y.M. et al. 2008. Change in MSW characteristics under recent management strategies in Taiwan. Waste Management, 28, 2443-2455, DOI: 10.1016/j.wasman.2007.10.014

6. Dahlén L., Lagerkvist A. 2010. Pay as you throw: strengths and weaknesses of weight based billing in household waste collection systems in Sweden. Waste Management, 30(1), 23-31, DOI: 10.1016/j. wasman.2009.09.022

7. DijkgraafE., Gradus R.H.J.M. 2009. Environmental activism and dynamics of unit based pricing systems. Resource and Energy Economics, 31, 13-23, DOI:10.1016/j.reseneeco.2008.10.003

8. Gellynck X., Verhelst P. 2007. Assessing instruments for mixed household solid waste collection services in the Flemish region of Belgium. Resources, Conservation and Recycling, 49(4), 372-387, DOI: 10.1016/j.resconrec.2006.05.003.

9. Goleń M. 2014. Problemy kształtowania przez gminy opłat za zagospodarowanie odpadami komunalnymi w świetle nowelizacji ustawy o utrzymaniu czystości i porządku w gminach. Studia i prace. Kolegium Zarządzania i Finansów. Zeszyt naukowy No. 138, 125-141. Publishing House of Warsaw School of Economic in Warsaw, Warsaw 2014.

10. Grzymała Z., Maśloch G., Goleń M., Górnicki E. 2013. Racjonalizacja gospodarki odpadami komunalnymi w Polsce w świetle zmian Ustawy o utrzymaniu czystości i porządku w gminach, Publishing House of Warsaw School of Economic in Warsaw, Warsaw 2013.

11. Kiepas-Kokot A., Łysko A., Nowak M.J., 2015. Zróżnicowanie obciążeń gospodarstw domowych z tytułu opłat za gospodarowanie odpadami w gminach województwazachodniopomorskiego. Ekonomia i Środowisko, 54(3), 154-168.

12. Kołaczek E. 2012. Nowy system gospodarki odpadami komunalnymi. Ministry of the Environment. Waste Management Department. Warsaw 2012.

13. Lichovníková, V., Št’astná, M., Kotovicová, J., Vaverková, M.D., Adamcová, D. 2015. The influence of the solid waste landfill existence on the 
environmental and economic situation of Petrůvky village (Czechia). Europ. Countrys. 4, 179-194.

14. Malinowski M. 2014. Analiza kosztów zbierania i transportu zmieszanych odpadów komunalnych. Infrastruktura i Ekologia Terenów Wiejskich, No. IV/2/2014, 1179-1191.

15. Malinowski M., Grzelec K., Gutwin M., 2018. Analiza zanieczyszczeń w selektywnie gromadzonych odpadach tworzyw sztucznych - studium przypadku. Infrastructure and Ecology of Rural Areas. 2/1, 465-478. doi: 10.14597/infraeco.2017.2.1.031.

16. Malinowski M., Łukasiewicz M., Famielec S., Nowińska K. 2019. Analysis of changes in fees for the collection and management of municipal waste as regards the efficiency of waste segregation . Ekonomia i środowisko, 2(69), 24-41. DOI: https://doi.org/10.34659/2019/2/19.

17. National Waste Management Plan 2022. Resolution No. 88 of the Council of Ministers of July 1, 2016

18. Sakai S. et al. 2008.Unit-charging programs for municipal solid waste in Japan. Waste Management, 28, 2815-2825, DOI: 10.1016/j.wasman.2008.07.010.
19. Sierak J. 2014. Wybrane problemy finansowania gospodarki odpadami komunalnymi. Studia i prace. Kolegium Zarządzania i Finansów. Zeszyt naukowy nr. 138, 75-102..

20. Steinhoff-Wrześniewska A. 2015. The preparing communities at rural areas for waste management in the light of new regulations. Archiwum Gospodarki Odpadami i Ochrony Środowiska, 17(2), 49-58.

21. Terek K.; Piotrowska A. 2013. Płacić każdy możetrochę taniej lub trochę drożej. Przegląd Komunalny, 4, 49-53.

22. Töpfer K. (ed.) 2005. Selection, Design and Implementation of Economic Instruments in the Solid Waste Management Sector in Kenya The Case of Plastic Bags, United Nations Environment Programme, www.unep.ch/etb/publications/EconInst/ Kenya.pdf [17-08-2019].

23. Van Beukering P.J.H. et al. 2009. Effectiveness of unit-based pricing of waste in theNetherlands: applying a general equilibrium model, "Waste Management" 29(11), 2892-2901, DOI: 10.1016/j.wasman.2009.07.002. 